\title{
Learning Style among Native Iban Students Based on Their Gender in Acquiring Malay as a Second Language
}

\author{
Vijayaletchumy Subramaniam ${ }^{1}$, Batik Baidin ${ }^{2}$, Rashid Melebek ${ }^{1} \&$ Chyn-Chye Yong $^{3}$ \\ ${ }^{1}$ Faculty of Modern Languages and Communication, Universiti Putra Malaysia, Selangor, Malaysia \\ ${ }^{2}$ SMK Petra Jaya, Kuching, Sarawak, Malaysia \\ ${ }^{3}$ Learning Institute for Empowerment, Multimedia University, Cyberjaya, Malaysia \\ Correspondence: Vijayaletchumy Subramaniam, Faculty of Modern Languages and Communication, Department \\ of Malay Language, Universiti Putra Malaysia, Selangor 43400, Malaysia. Tel: 60-3-8946-8769. E-mail: \\ letchumy1617@gmail.com
}

$\begin{array}{lr}\text { Received: March 18, } 2014 & \text { Accepted: April 1, } 2014 \quad \text { Online Published: May 30, } 2014 \\ \text { doi:10.5539/ass.v10n11p194 } & \text { URL: http://dx.doi.org/10.5539/ass.v10n11p194 }\end{array}$

\begin{abstract}
Most of the teachers pay less focus on students' learning styles due to their obligation to finish the syllabus within the specified duration, which often resulted in the mismatched of teaching process and learning outcomes. This study aims to identify the different learning styles across gender in acquiring Malay language as a second language among native Iban students in Sarawak. 170 students were chosen from five high schools in Betong region (Sarawak) for analysis, based on the Dunn and Dunn Learning Model (1992). A combination of questionnaire survey and interviews helps to concrete our findings. Results reveal similarities in learning styles across gender in terms of emotional stimulation, psychological, environmental, and physiological factors but differences in sociological stimulation. On the whole, students have deep intrinsic motivation, low desire but positive sense of responsibility, and find it easier to learn Malay language via bonded learning structure compared to liberal ones.
\end{abstract}

Keywords: learning styles, Malay language as a second language, native Iban students, gender

\section{Introduction}

Mastery of Malay language is very important for all students regardless of race because it serves as the language of instruction in national schools in this country. Thus, learning styles of each student in learning the Malay language should be addressed. Most of the teachers who teach Malay language put less emphasis on a student's learning style due to their obligation to finish the content outlined in the syllabus, and completing it within the specified duration. Apart from that, Robiah Hamid's opinion (1996) in Asiah Haji Pariekulty (1999) might also be true in reflecting this problem, that is, although teacher's planning takes into account students' academic performance differences to suit the learning strategies are encouraged, teachers' understanding about learning styles among students is minimum. In such situations, students certainly become less exposed to a variety of learning styles. Therefore, this study which aims to identify the different learning styles among male and female native Iban students in acquiring Malay language as a second language has to be conducted, and hopefully can help teachers to diversify their teaching styles to suit the students' interests of both the gender because according to Sims and Sims (in Norlia Abdul Aziz, 2001), effective learning style for a particular student may not be appropriate for other students. It is clear that the role of the teacher is very important to identify the learning style of each student learning Malay language because if Malay language is taught and learnt in an enjoyable style, it will not only enable the students to achieve excellent grades in tests and examinations in school, but also enhance their ability to think, and thus able to develop the intellectual capacity of the individual. This study will help all those involved in education, whether at the Ministry of Education (KPM), Teacher Education Division (BPG), teacher's training college, teachers who are teaching Malay Language, school administrators and education authorities or curriculum planners. Besides that, this research is also important for native students in Sarawak especially native Iban students where Malay language is their second language. In addition, this research is also important for the native students in Sarawak and also their parents as they also play an important role in the children's education. 


\section{Literature Review}

There are quite a number of previous local or foreign studies that had been carried out in connection with the learning styles of students studying in primary school up to university level using a variety of learning models. Thus, this research which aimed to identify learning styles employed in learning Malay language as a second language among native Iban students in Sarawak based on their gender is of significant importance because the results from this research would surely benefit the education system in this country.

Previous studies conducted by Oxford (1995) on learning English as a second language based on gender among college students in the United States have found that girls tend to prefer auditory learning style compared to male students. Although gender is typically a significant factor another disciplines in particular in educational and psychological research, gender has only received sporadic attention in the studies of language learning strategies. Therefore is an attempt to explore the influence of gender on language strategy use. Lincoln and Rademacher (2006) which also examined learning styles based on gender found that visual learning style and kinaesthetic were most favoured by both male and female respondents. However, many male students prefer kinaesthetic learning styles than female students. In addition, $71 \%$ of female students prefer aural learning styles, and two thirds of the girls also chose multimode learning styles. The study also found that female students choose auditory and multimodal learning style, whilst male students preferred to learn by copying notes. Meanwhile, Marzalina Mansor (2004), in her research related to the learning styles of Malay language as a foreign language among overseas students found that Malay language learning style which is dominantly used by foreign students learning style is based on the psychological element namely reflective learning. It was found that Arab foreign students were more dominant in Malay learning styles with psychological elements compared to foreign student from Bangladesh and Vietnam who were dominant in sociological elements. In contrast, foreign students from Ethopia and other foreign students were more dominant in learning style based on environmental elements. In addition, the study also proves that there are differences in Malay language learning styles between foreign male and female students.

Zubaidah Ahmad Ishak (1999) has made a study of the relationships between academic achievement and learning style involving 64 Form Four students in SMK SS17 Subang Jaya, Selangor consisting of 29 male and 35 female students. The study found that students show high tendency in the physical dimension of learning style, very prone to various activities either in groups or individually during the learning process. These findings also indicate that emotional dimension was the second choice, sociological dimension being the third choice, and students have the least tendency towards dimensional environment. Based on the reasons described, it is clearly proven that there was a more significant tendency towards physical dimensions compared with other dimensions.

A study conducted by Honigsfeld and Dunn (2009) throughout the United States of America found that standard tests in schools tend to be analytical and sequential cognitive. The common approach to teaching in secondary schools is carried out using the traditional method using chalk and talk, lectures, writing notes, reading, topical test after a topic. However, the examination results showed the number of students who are failing to pass were poor with such traditional teaching methods. Next, a study by Lister $(2004,2005)$ conducted among students in Bermuda to compare the efficacy of traditional teaching methods with teaching method using tactual-kinaesthetic resources. The researcher used the same learning content. The study found that the achievement of students taught by using tactual-kinaesthetic resources in secondary schools that fell under failing to pass category increased, and also found that many students were interested in teaching with tactual and kinaesthetic resources compared to traditional ones.

Crossley (2007), focused his research on the comparative effectiveness of Multisensory Instructional Package with traditional teaching approach to demonstrate achievement in science subjects and test scores in attitudes among two group of students. The sample included the students who use English as a first language and those students who do not use it as a first language. The students were taught using traditional teaching approaches and multi-sensory teaching approaches in three units of learning. The research found that there was a significant impact on the achievement of science subjects and also the attitude test scores after multi-sensory teaching was employed in teaching. According to Kress (2000), teachers talked for too long in the traditional approach, and write with chalk which only make the students become bored and cause them to lose concentration. Therefore, to create a more enjoyable learning environment, teachers must use a form of multi modal learning using a variety of styles that can stimulate the minds of students in teaching and learning. Auditory skill is not intelligence but a sense necessary in teaching and learning. In this case, Gardner (2003) noted that the use of the traditional approach is less effective because people have multiple intelligences, and every individual is different in terms of 
genetics and experience related to the strengths and weaknesses of intellectual power. We cannot create the impression that there are artistic or non-artistic intelligence, but a variety of intelligence can be aesthetically matched if the individual wants it. Furthermore, Vogt, Jordan and Tharp (1987) argue that students who are at low academic achievement will only succeed in learning when teachers change their teaching style and adapt it to the students' preferred learning styles.

Next, Shaughnessy (1998) have reported that as many as 42 times of comprehensive experimental studies have been made between 1980 and 1990 by 13 higher learning institutions in the United States. The results show that, students who were allowed to learn by using their own preferred learning styles have been able to achieve up to $75 \%$ higher standard deviation than students who learn in the manner prescribed by the teacher, instead of their own choice. In addition, schools across the United States were reported to attain higher test scores or grade point average in all levels within six weeks after the students were encouraged to learn according to their own preferred style.

Regarding the above case, the role of the teacher is important in understanding the preferred learning styles of their students so that what is being taught by the teachers is understood and classroom learning experience will be lively, fresh, and valuable knowledge is acquired which can be applied in real life.

\section{Methodology}

This study is based on Dunn and Dunn Learning Model (1992) was constructed based on a theory that each student has a different learning style. The study is limited to 170 native Iban students studying in Form Four in five schools in Betong region, Sarawak, namely SMK Saratok, SMK Bahasa Malaysia, Saratok, SMK Kalaka, Roban, SMK Saribas, Debak and SMK Ulu Layar, Betong. This study focused on differences in learning style employed in learning Malay language as a second language among native Iban students based on their gender. This study is conducted by using literature method, survey using a questionnaire, and interviews. Research instruments consist of specially designed questionnaire according to the research needs and is divided into two parts. Part A contains items related to demographic information of the respondents, whilst Part B is a survey on Malay language learning styles based on Dunn and Dunn Learning Model (1992) which highlighted five factors, namely emotional stimulus factors, environment, psychology, physiology, and sociology. Interview methods used to interview teachers who teach Malay language subject for Form Four in the schools involved discovering and identifying the problems faced by teachers during Malay language teaching and learning processes among these native Iban students. Data analysis was conducted using qualitative and quantitative approaches with data processing carried out using SPSS to acquire the frequencies and percentages. Relevant factors were descriptively discussed.

\section{Study Findings}

4.1 Identify Subsections Malay Language Learning Style as the Second Language among Native Iban Male and Female Students in Sarawak

Respondents are students who use Iban language as their first language, aged between 16 and 17 and are studying in Form Four in the secondary school in the rural area in Betong Division, Sarawak. From 170 respondents, as many as 112 respondents representing $65.9 \%$ are female students, and the rest, 58 respondents representing $34.1 \%$ are male students (Table 1 ).

Table 1. Analysis based on the background of respondent

\begin{tabular}{|c|c|c|c|c|c|c|c|c|}
\hline \multirow[b]{2}{*}{ Stimulant } & \multicolumn{4}{|c|}{ Male Students (58 Students) } & \multicolumn{4}{|c|}{ Female Students (112 Students) } \\
\hline & Agree No. & $\%$ & Disagree No. & $\%$ & Agree No. & $\%$ & Disagree No. & $\%$ \\
\hline \multicolumn{9}{|l|}{ A) Emotion } \\
\hline \multicolumn{9}{|l|}{ a) Motivation } \\
\hline i) Intrinsic & 41 & 70.7 & 17 & 29.3 & 82 & 73.2 & 30 & 26.8 \\
\hline ii) Extrinsic & 24 & 41.4 & 33 & 55.9 & 27 & 24.1 & 85 & 75.9 \\
\hline \multicolumn{9}{|l|}{ b) Determination } \\
\hline i) high & 8 & 13.8 & 49 & 86.0 & 28 & 25.0 & 84 & 75.0 \\
\hline ii) low & 52 & 87.9 & 6 & 10.3 & 100 & 89.3 & 12 & 10.7 \\
\hline c) Responsibility & & & & & & & & \\
\hline
\end{tabular}




\begin{tabular}{|c|c|c|c|c|c|c|c|c|}
\hline \multirow[b]{2}{*}{ Stimulant } & \multicolumn{4}{|c|}{ Male Students (58 Students) } & \multicolumn{4}{|c|}{ Female Students (112 Students) } \\
\hline & Agree No. & $\%$ & Disagree No. & $\%$ & Agree No. & $\%$ & Disagree No. & $\%$ \\
\hline i) positive & 55 & 94.8 & 3 & 5.2 & 110 & 98.2 & 2 & 1.8 \\
\hline ii) negative & 22 & 37.9 & 36 & 62.1 & 28 & 25.0 & 84 & 75.0 \\
\hline \multicolumn{9}{|l|}{ d) Structure } \\
\hline i) liberal & 29 & 50.0 & 29 & 50.0 & 70 & 62.5 & 42 & 37.5 \\
\hline ii) confined & 54 & 93.1 & 4 & 6.9 & 105 & 93.8 & 7 & 6.2 \\
\hline \multicolumn{9}{|l|}{ B) Psychology } \\
\hline a) Reflective & 57 & 98.3 & 1 & 1.7 & 106 & 94.6 & 6 & 5.4 \\
\hline b) Impulsive & 17 & 29.3 & 41 & 70.7 & 25 & 22.3 & 87 & 77.7 \\
\hline c) Analitical & 51 & 87.9 & 7 & 12.1 & 103 & 92.0 & 9 & 8.0 \\
\hline d) Global & 30 & 51.7 & 26 & 44.8 & 53 & 47.3 & 59 & 52.7 \\
\hline \multicolumn{9}{|l|}{ e) Hemisphere } \\
\hline i) left & 39 & 67.2 & 18 & 31.0 & 78 & 69.6 & 34 & 30.4 \\
\hline ii) right & 40 & 69.0 & 18 & 31.0 & 81 & 72.3 & 31 & 27.7 \\
\hline \multicolumn{9}{|l|}{ C) Environment } \\
\hline \multicolumn{9}{|l|}{ a) Design } \\
\hline i) classroom & 46 & 79.3 & 12 & 17.2 & 98 & 87.5 & 14 & 12.5 \\
\hline ii) dormitory/accommodation & 53 & 91.4 & 5 & 8.6 & 102 & 91.1 & 10 & 8.9 \\
\hline b) Temperature & 45 & 77.6 & 13 & 22.4 & 86 & 76.8 & 25 & 23.2 \\
\hline c) Sound & 52 & 89.6 & 6 & 10.4 & 89 & 79.5 & 23 & 20.5 \\
\hline d) Light & 41 & 70.7 & 17 & 29.3 & 82 & 73.2 & 30 & 26.8 \\
\hline \multicolumn{9}{|l|}{ D) Physiology } \\
\hline \multicolumn{9}{|l|}{ a) Perception } \\
\hline i) auditory & 5 & 8.6 & 53 & 91.4 & 7 & 6.2 & 105 & 93.8 \\
\hline ii) visual & 11 & 19.0 & 47 & 81.0 & 18 & 16.1 & 94 & 83.9 \\
\hline iii) kinesthetic-tactile & 51 & 87.9 & 7 & 12.1 & 103 & 90.0 & 9 & 10.0 \\
\hline b) Study time & 47 & 81.0 & 11 & 19.0 & 87 & 77.7 & 25 & 22.3 \\
\hline c) Movement & 37 & 64.0 & 21 & 36.0 & 73 & 65.2 & 38 & 34.8 \\
\hline d) Food and drinks & 25 & 43.1 & 33 & 56.9 & 53 & 47.3 & 59 & 52.7 \\
\hline \multicolumn{9}{|l|}{ E) Sociology } \\
\hline a) Independent & 22 & 37.9 & 36 & 62.1 & 54 & 48.2 & 58 & 51.8 \\
\hline b) Peers & 22 & 37.9 & 36 & 62.1 & 64 & 57.1 & 48 & 42.9 \\
\hline c) Adults & 48 & 82.8 & 10 & 17.2 & 105 & 93.8 & 7 & 6.2 \\
\hline d) Pair & 48 & 82.8 & 10 & 17.2 & 85 & 75.9 & 27 & 24.1 \\
\hline e) Group & 49 & 84.5 & 9 & 15.5 & 85 & 75.9 & 27 & 24.1 \\
\hline
\end{tabular}

\subsubsection{Emotional Stimulation}

In the emotional stimulation, it is found that the majority of native Iban male and female students in Sarawak all possess high intrinsic motivation. It is proven that $41(70.7 \%)$ are male students, and $82(73.2 \%)$ female students had chosen intrinsic motivation as compared to extrinsic motivation meaning that most students were inclined and motivated to learn Malay Language innately, and that they do not need any kind of reward. Next, the majority of male and female students are found to have low determination but have positive responsibility. As evidence, $52(87.9 \%)$ are male, and $100(89.3 \%)$ female chose low determination which indicates that students were not able to learn for long periods of time continuously, thus they needed to have a break before proceeding 
with their studies. However, the findings suggest that the respondents are very responsible, and they make effort to complete the Malay Language tasks given by their teachers. This is proven through the study findings which show that $55(94.8 \%)$ male students, and $110(98.2 \%)$ female students agreed with the element of positive responsibility compared to the element of negative responsibility. Next, the findings show that students, whether male or female were comfortable with the learning style with the bound structure as compared to the liberal structure, which is 54 (93.1\%) male students, 105 (93.8\%) female students chose the element bound structure while learning Malay Language which shows that they really needed a teacher to guide them in revising and learning the language.

\subsubsection{Psychological Stimulation}

In psychological stimulation, both genders had chosen the reflective learning style as compared to the impulsive learning style, where evidently 57 (98.3\%) male, and 106 (94.6\%) female had agreed with this element. This explains that the respondents were interested to know new things taught to them, and at the same time they were always looking closely into the tasks with high suspicion. Students had selected analytical learning compared to global learning. $51(87.9 \%)$ male and $103(92.0 \%)$ female students were drawn to the analytical learning style indicating that they would analyse a topic or sub-topic in the learning of Malay Language carefully and in detail. For the element of brain hemisphere, $39(67.2 \%)$ male, and $78(69.6 \%)$ females have a dominant left-side of the brain, whereas $40(69.0 \%)$ male and $81(72.3 \%)$ female have dominant right brain. This demonstrates that most female students have dominant right brain than left, that they are inclined to use their creativity and imagination in completing their Bahasa tasks, and among the male students there is not much difference between the dominance of the right and the left side of the brain, that they are creative and imaginative and simultaneously, think logically and rationally.

\subsubsection{Environmental Stimulation}

For environmental stimulation, both genders were comfortable learning Malay Language aided by the element of the design of the hostel or accommodation or neat accommodation with the furniture arranged in a formal and traditional manner. Study findings show that $53(91.4 \%)$ male and $102(91.1 \%)$ female agreed with this element. The formal and systematic classroom design was also chosen, by $46(79.3 \%)$ male and $98(87.5 \%)$ female students. Most students from both genders liked learning Malay Language in silence, represented by $52(89.7 \%)$ male students, and 89 (79.5\%) female students, any loud noise will distract their concentration. The elements of temperature and light were also of choice among the respondents. The finding shows that $45(77.6 \%)$ male and $86(76.8 \%)$ female students agreed with the temperature element, while $45(77.6 \%)$ male and $82(73.2 \%)$ female chose the element of light. Such findings prove that most students will be able to learn Malay Language as their second language more comfortably when the environment is a little colder and the space is brighter.

\subsubsection{Physiology Stimulation}

In physiology stimulation, the element of kinesthetic-tactile had become the main choice by both genders as compared to the visual and auditory, whereby 51 (87.9\%) male and $103(92.0 \%)$ female students had chosen this kinesthetic-tactile element. The study findings prove that the respondents will enjoy educational trips to places that relate with learning as they are able to see the actual conditions. Malay Language learning using audio-visual aid such as the radio, cassette tapes, or power point did not really appeal to these students. Next, they were found to be more comfortable learning in the early morning, compared to late at night, and evidently $47(81.0 \%)$ male and $87(77.7 \%)$ female had chosen the element of learning in the early morning. The movement element was marked by $37(64.7 \%)$ male and $73(65.2 \%)$ female students. The element of food and drinks did not really fare well among the respondents, whereby 25 (43.1\%) male and $53(47.3 \%)$ female students had agreed with this element.

\subsubsection{Sociological Stimulation}

For sociological stimulation, the study findings show that 49 male students $(84.5 \%)$ had chosen to learn in groups, as compared to other elements, whereas 105 (93.8\%) female students had preferred to learn with adults. Nonetheless, learning with adults and learning in pairs were still popular choices among male students, which is $48(86.2 \%)$ male students, respectively. The element of learning with peers and learning independently did not really appeal to both gender. This proves that the role of teachers (as an example of adult) is important as the motivator in the learning of Malay Language.

\section{Conclusion}

As a whole, the study findings show that there are similarities in the learning style of Malay Language as the second language among Iban native male and female students in Sarawak in terms of the emotional, 
psychological, environmental and physiological stimulations. Nonetheless, their learning style is found to be different from the field of sociological stimulation, whereby the majority of female students had chosen to learn with adults while the male counterparts preferred to learn in groups. Meanwhile, the study findings have found that the majority of male students are more prone to adopt the learning style based on the reflective learning of the psychological element while the girls are more inclined towards the learning style based on the emotional element of positive responsibility. The similarities and differences of the learning style obtained by the study findings show that every Iban native is inclined to the variety of learning styles, and does not deviate from the stimulations proposed in the Dunn and Dunn's Learning Model (1992), namely the emotional, psychological, environmental and physiological stimulations. Thus, to improve the interest and performance of Iban students in the subject of Malay Language, the chosen learning style must be given due attention and cannot be dismissed by relevant parties. The learning styles that they have chosen must be exploited and considered in the teaching and learning Malay Language to retain the sense of responsibility that has long been embedded and to sustain high intrinsic motivation already existed among these native students.

\section{References}

A column sponsored by ABC. (2009). Teaching Methodology and Concepts Committee. In M. A. Dyrud (Ed.), Focus on Teaching. Business Communication Quaterly (Vol. 60, pp. 124-134). Retrieved from http://bcq.sagepub.com/cgi/pdf-extract/60/2/14

Abdullah, H. (1987). 30 Tahun Perancangan Bahasa Malaysia. Kuala Lumpur: Dewan Bahasa dan Pustaka.

Abdullah, H. (1987). Isu-isu Perancangan Bahasa: Pengintektualan Bahasa Malaysia. Kuala Lumpur: Dewan Bahasa dan Pustaka.

Asiah Bt, H. P. (1999). Gaya Pemelajaran dan Pencapaian Akademik di Kalangan Pelajar-pelajar Tingkatan Empat di Sekolah Menengah Teknik Juasseh, Kuala Pilah, Darul Khusus. (Unpublished master's thesis). Universiti Malaya.

Asmah, H. O. (1988). Susur Galur Malay Language. Kuala Lumpur: Dewan Bahasa dan Pustaka.

Awang, S. (2005). Perjuangan Bahasa Kebangsaan di peringkat antarabangsa. Jurnal Dewan Bahasa, 5(1), 54-57.

Cense, A. A., \& Uhlenbeck, E. M. (1958). Critical Survey of Studies on the Language of Borneo. The Hague Gravenhage-Martimus Nijhoff.

Crossley, H. (2007). Effects of Traditional Teaching Versus a Multisensory Instructional package on The Science Achievement and Attitudes of English-Language Learners versus other middle-school minority students. (Unpublished doctoral dissertation). St. John's University.

Cuthbert, P. F. (2005). The student learning process: Learning Styles or Learning Approaches? Teaching in Higher Education, 10(2), 235-249. http://dx.doi.org/10.1080/1356251042000337972

Desmedt, E., \& Valcke, M. (2004). Mapping the learning styles. An overview of the literature based on citation analysis. Educational Psychology, 24, 445-464. http://dx.doi.org/10.1080/0144341042000228843

Duff, A. (2002). Learning Styles measurement: The revised approaches to studying inventory (RASI). Bristol Bussiness School Teaching and Research Review. Retrieved from http://www.edam.com.tr/kuyeb/en/onke_sayilar.asp?act=datay\&ID=35

Dunn, R., \& Dunn, K. (1978). Teaching Students through Their Individual Learning Styles: A Pratical Approach. Reston. Va: Reston Publishing Co.

Dunn, R., \& Dunn, K. (1992). Teaching Elementary Students through Their Individual Learning Students: Pratical Approach for Grades 3-6. Needham Height, Massachussets 02194: Allyn and Bacon.

Dunn et al. (2009). Retrieved from http:/www.highbeam.com/doc/igi-191327563.html

Elizabeth, S. M. T. (2000). Gaya Pembelajaran dan Hubungannya dengan Pencapaian Matematik: Satu Kajian Kes di Malaysia France Institute (MFI) (Unpublished master's thesis). Universiti Kebangsaan Malaysia.

Entwistle, N. J. (1988). Motivational Factors in Students, Approaches to Learning. In R. R. Schmedk (Ed.), Learning Strategies and Learning Styles (pp. 21-51). New York: Plenum Press. http://dx.doi.org/10.1007/978-1-4899-2118-5_2

Felder, R. M., \& Brent, R. (2005). Understanding student differences. Journal of Engineering Education, 94(1), 57-72. http://dx.doi.org/10.1002/j.2168-9830.2005.tb00829.x 
Gardner, H. (2003). Multiple Intelligences after Twenty Years. Paper work presented in American Educational Research Association.

Honigsfield, A., \& Dunn, R. (2009). Learning-Style Responsive Approaches for Teaching Typically Performing and At-Risk Adolescents. The Clearing House, 82(5), 220-224. http://dx.doi.org/10.3200/TCHS.82.5.220-224

Malaysian Statistical Department, Sarawak. (2005). Buletin Perangkaan Bulanan Sarawak 2005 Disember. Sarawak: Sarawak Statistical Department.

Kress, G. (2000). Multimodality. In B. Cope, \& M. Kalantzis (Eds.) Multiliteracies: Literacy Learning and the Design of Social Futures (pp. 10-12). London: Routledge.

Laporan Jawatankuasa Mengkaji Penggunaan Malay Language. (1981). Kuala Lumpur: Dewan Bahasa dan Pustaka.

Lembaga Peperiksaan Malaysia. (2011). Retrieved from http://www2.moe.gov.my/ lp/faq_spm.htm

Lincoln, F., \& Rademacher, B. (2006). Learning styles of ESL Students in Community Colleges. Comminity College Journal of Research and Practice, 30, 485-500. Arkansas: Taylor \& Francis Group, LCC. http://dx.doi.org/10.1080/10668920500207965

Lindemann, R. A., Duek, J. \& Wilkerson, L. (2001). A comparison of changes in dental students' and medical students' approaches to learning during professional training. European Journal of Dental Education, 5, 162-167. http://dx.doi.org/10.1034/j.1600-0579.2001.50404.x

Lister, D. (2004). Comparisons Between the Learning Styles of Underachieving and Regular Education Sixth Grade Bermudian Students and the Effects of Responsive Instruction on the Former's Social Studies Achievement, and Attitude-test Scores (Unpublished doctoral dissertation). St. John's University.

Lister, D. (2005). Effects of traditional versus tactual and kinesthetic learning-style responsive instructional strategies on Bermudian learning-support sixth grade students' social studies achievement, and attitude-test scores. Research for Educational Reform, 10(2), 24-40.

Liu, Y., \& Ginther, D. (1999). Cognitive styles and distance education. Online Journal of Distance learning Adiminstration, 2(3). Retrieved from http://www.westga.edu/ distance/ojdla/fall23/liu23.html.

Marzalina Bt. Mansor. (2004). Stail Pembelajaran . Malay Language Sebagai Bahasa Asing dalam Kalangan Pelajar Luar Negeri (Unpublished master's thesis). Universiti Putra Malaysia.

Norlia Abdul Aziz. (2001). Hubungan Antara Gaya Pembelajaran dengan Pencapaian Matematik Tambahan Pelajar Tingkatan 4. (Unpublished master's thesis). Universiti Kebangsaan Malaysia.

Oxford, R. (1995). Gender Differences in Language Learning Styles: What Do They Mean? In J. Reid (Ed.), Learning Style in The ESL/EFL Classroom (pp. 34-37). New York: Heinle \& Heinle.

Perlembagaan Persekutuan. (1970). Education Ministry, National printing Department: Kuala Lumpur.

Shaughnessy, M. (1998). An Interview with Rita Dunn about Learning Styles. The Clearing House, 71(3), 141-145. http://dx.doi.org/10.1080/00098659809599346

Teo, K. S. (2003). Cabaran Malay Language dalam Era Globalisasi. Jurnal Dewan Bahasa, 3(8), 5-6.

Vogt, L. A., Jordan, C., \& Tharp, R. G. (1987). Explaining school failure, producing school success: Two cases. Anthroplogy and Education Quaterly, 18, 212-219. http://dx.doi.org/10.1525/aeq.1987.18.4.04x0019s

Zubaidah, A. I. (1999). Perhubungan Antara Gaya Pembelajaran dengan Pencapaian Akademik (Unpublished master's thesis). Universiti Malaya.

Zulkifli, O. (2003). Satu Bahasa, Satu bangsa, Satu Nusa. Jurnal Dewan Bahasa, 3(9), $20-27$.

\section{Copyrights}

Copyright for this article is retained by the author(s), with first publication rights granted to the journal.

This is an open-access article distributed under the terms and conditions of the Creative Commons Attribution license (http://creativecommons.org/licenses/by/3.0/). 